\title{
KALAM KLASIK DAN KALAM KONTEMPORER (STUDI KONSTRUKSI METODOLOGI)
}

\author{
M. Kursani Ahmad \\ Jurusan Akidah Filsafat Fakultas Ushuluddin Dan Humaniora \\ IAIN Antasari Banjarmasin
}

\begin{abstract}
The methodology of kalam in Islamic thought was born and developed by islamic experts as an attempt to translate the values of universality al-Quran and al-Hadith. Here, they expressed his views of kalam, then maintained it through rational-logical argument, which is adapted to the circumstances age. The methodology of classical kalam thinking was the answers to the problems of kalam in passed time, which can be identified as from political strife, and philosophical mindset, especially for flow of kalam which have relation with the Greek philosophical thought, and it's theocentric oriented. While the methodology of kalam contemporary thought have in touch with contemporary Western philosophical thought today, its presence is not merely an attempt apoligetike defending God, but that is more anthropocentric expected to help, overcome and solve the problems of society today.
\end{abstract}

Kata kunci: kalam klasik, kalam kontemprer, metodologi

\section{Pendahuluan}

Ilmu Kalam menempati posisi yang sangat penting dalam ajaran Islam, sebab segala persoalan keagamaan yang berhubungan dengan ketuhanan, selalu saja ditelaah dari perspektif ilmu kalam. Dengan mempelajari dan memahaminya secara mendalam diharapkan bisa mendapatkan keyakinan dan pedoman yang kokoh dalam beragama, sehingga tidak mudah diperdaya oleh perkembangan zaman yang selalu berubah-ubah, karena setiap gerak dan langkah, tindakan dan perbuatan selalu dilandaskan pada keyakinan yang dijadikan sebagai pegangan hidup keseharian.

Dalam perkembangan pemikiran kalam dikenal dengan metodologi pemikiran kalam klasik dan metodologi pemikiran kalam kontemporer. Pemikiran kalam klasik yang dalam aliran kalam di antaranya, seperti Mu'tazilah, Asy'ariyah danSalafiyah, merupakan awal tonggak sejarah metodologi pemikiran kalam dalam khazanah intelektual Islam klasik, yang sampai sekarang masih dikaji dan dipelajari di berbagai pusat pendidikan formal maupun non formal. Mengapa corak metodologi pemikiran kalam klasik ini dapat bertahan sedemikian kokoh sampai sekarang, padahal hampir semua rumusan pemikiran kalam klasik merupakan warisan alam pemikiran filsafat Yunani kuno, yang telah mengalami perubahan yang cukup fundamental sesuai dengan perkembangan zaman dan tantangan yang dihadapinya.

Walaupun metodologi pemikiran kalam klasik merupakan bagunan pemikiran kalam yang dibentuk oleh zaman yang berkembang pada saat itu. Tentunya pemikirannya tidak bersifat mutlak benar, tetapi harus diikuti oleh tradisi pemikiraan keagamaan yang bersifat sikap kritis. Karena perbedaan muatan pengalaman dan penghayatan zamannya akan menyebabkan perbedaan rumusan, termasuk rumusan pemikiran metodologi kalam itu sendiri, sehingga bangunan tradisi keagamaan selalu up to date dan tanggap dengan tantangan zaman. 
Untuk itulah, dalam menghadapi dan menyikapi perkembangan pemikiran Islam pada era modern/kontemporer sekarang ini (1800 M - sekarang) merupakan zaman kebangkitan umat Islam dan keinginan untuk tetap melestarikan tradisi keilmuan pemikiran klasik yang lebih khusus pada metodologi pemikiran kalam klasik. Tentunya kecunderungan pemikiran Islam kontemporer bisa dijadikan inspirasi untuk melakukan evaluasi kritis terhadap metodologi kalam, dan mendorong kita untuk melakukan kritik ulang terhadap pemikiran kalam selama ini, yang disesuaikan dengan situasi dan perkembangan pada era kontemporer saat ini.

Sehubungan dengan itu, maka dalam tulisan ini penulis berusaha akan menampilkan sebuah diskripsi tentang rancang bangun metodologi pemikiran kalam klasik dan metodologi pemikiran kalam kontemporer, yang didahului dengan pemahaman tentang metodologi kalam dan disertakan sebuah analisa perbandingan untuk melihat sejauhmana persamaan dan perbedaan antara kedua metodologi pemikiran tersebut.

\section{Metodologi Kalam}

Metodelogi ${ }^{1}$ yang dimaksud dalam tulisan ini adalah yang berkaitan dengan salah satu bidang ilmu filsafat yaitu berkenaan dengan masalah epistemologi ${ }^{2}$ yang dihasilkan dan dibentuk oleh suatu peradaban, dengan demikian epistemologi mengatur semua aspek studi manusia dari filsafat sampai ilmu sosial.

Dengan demikian epistemologi kalam klasik yang kita kenal sekarang ini, dibentuk dari suatu peradaban pada masanya, demikian pula halnya epistemologi kalam kontemporer harus dikembangkan berdasarkan peradaban masanya pula. Hal ini tidak berarti epistemologi kalam klasik untuk masa kontemporer sekarang ini tidak diperlukan lagi keberadaannya, tetapi melalui kalam klasik kita lebih dapat mengembangkannya dengan memiliki wawasan dan visi baru tentang metodologi kalam tersebut sesuai dengan peradaban yang sedang berkembang, yang tentunya sangat mempengaruhi dinamika keberagamaan sesorang.

Untuk itulah seharusnya kita memahami betul metodologi pemikiran kalam kontemporer sekarang ini, sebagai wujud dari suatu peradaban kontemporer pula. Dimana kemajuan sains dan teknologi mendorong umat Islam untuk meninjau kembali disiplin keilmuan kalam. Tentunya metodologi pemikiran kalam kontemporer yang dimunculkan itu tetap tidak keluar dari prinsipprinsip dasar, yakni al-Qur'an dan al-hadis. ${ }^{3}$

Adapun persoalan yang sulit dipecahkan adalah yang berkenaan dengan masalah metodologi. Mengapa materi kalam terutama aspek metodologinya sulit dikembangkan sedemikian rupa, tidak seperti pada disiplin-disiplin ilmu lainnya, sehingga diharapkan dapat memberi bekal yang cukup bagi masyarakat dalam mengarungi kehidupan modern sekarang ini. Di mana pada era globalisasi agama dan budaya, umat Islam secara alamiah harus bersentuhan dan bergaul dengan budaya dan agama orang lain. Sering kali dijumpai bahwa umat Islam, baik secara individu maupun kelompok mengalami kesulitan keagamaan dan belum siap ketika harus berhadapan dengan arus dan gelombang

\footnotetext{
${ }^{1}$ Metodologi dari kata metode yang berarti cara yang teratur dan sistematis untuk pelaksanaan sesuatu, cara kerja. Sedangkan kata metodologi ialah ilmu metode, ilmu cara-cara dan langkah-langkah yang tepat (untuk menganalisa sesuatu), penjelasan serta menerapkan cara. Lihat Achmad Maulana, et.al.,Kamus Ilmiah Populer, (Yogyakarta: Absoulut, 2004), h. 306.

${ }^{2}$ Epistemologi berasal dari bahasa Yunani "episteme" dan "logos". Episteme artinya pengetahuan (knowledge), sedangkan kata logos berarti teori. Dengan demikian epistemologi secara etimologis berarti teori pengetahuan. Lihat Rizal Mustansyir dan Misnal Munir, Filsafat Ilmu, (Yogyakarta: Pustaka Pelajar, 23004), h. 16.

${ }^{3}$ Adeng Muchtar Ghazali, Perkembangan Ilmu Kalam Dari Klasik Hingga Modern, (Bandung: Pustaka Setia, 2005), h. 126
} 
budaya baru. Dalam kenyataan sering terjadi dalam masyarakat Islam bahwa mereka adalah selalu minoritas, padahal dalam statistik mareka adalah mayoritas. Demikian pula dalam masalah politik, umat Islam mengalami disartikulasi politik meskipun mereka mayoritas. Adakah andil yang dapat menyumbangkan oleh ilmu kalam dalam konfliks etnik, ras, suku dan agama selama ini? Rupaya bangunan keilmuan kalam klasik tidak menyediakan perangkat teori dan metodologi yang banyak menjelaskan bagaimana seorang agamawan yang baik harus berhadapan, bergaul, bersentuhan, berhubungan dengan penganut agama lain dalam alam praksis sosial, budaya, ekonomi dan politik. ${ }^{4}$

Menurut penelitian Fazlur Rahman, salah satu penyebab tidak berkembangnya disiplin keilmuan kalam, baik dalam segi materi maupun metodologinya adalah karena dipisahkan dan dihindarkanya pendekatan dan pemahaman filosofis dalam batang tubuh kerangka keilmuan kalam. Lebih lanjut menurut Fazlur Rahman, disiplin ilmu filsafat dan pendekatan filosofis pada umumnya sangat membantu untuk menerobos kemacetan, bahkan membantu jalan buntu yang dihadapai oleh ilmuilmu apapun. Bagaimanapun juga filsafat adalah merupakan alat intelektual yang terus menerus diperlukan. Untuk itu, ia harus boleh dikembangkan secara alamiah, baik untuk pengembangan filsafat itu sendiri maupun untuk pengembangan disiplin-disiplin keilmuan yang lainnya. Hal ini dapat dipahami, karena filsafat menanamkan kebiasaan dan melatih akal pikiran untuk bersifat kritis-analitis dan mampu melahirkan ide-ide segar yang sangat dibutuhkan, sehingga ia menjadi alat intelektual yang sangat penting untuk ilmu-ilmu yang lain, tidak terkecuali ilmu kalam itu sendiri. ${ }^{5}$

Untuk itulah menurut Fazlur Rahman perlu adanya metode yang jelas yang harus diterapkan oleh semua disiplin ilmu keislaman, termasuk ilmu kalam pada era kontemporer sekarang ini dan segera diupayakan systematic reconstruction dalam pemikiran Islam, terutama yang menyangkut bidang ilmu kalam. Sebab menurutnya, metodologi pemikiran klasik, seolah-olah tidak terpengaruh oleh perkembangan ilmu pengetahuan kontemporer. ${ }^{6}$ Oleh karena itu, perlunya dimanfaatkan temuantemuan ilmu sosial sebagai pertimbangan untuk memodifikasi, memperbaharui, menyegarkan dan membangun kembali konstruksi keilmuan dan metodologi kalam. ${ }^{7}$

Para generasi pemikir Muslim sekarang ini, di antaranya seperti Fazlur Rahman, Muhammad Arkoun, Hasan Hanafi, Nashr Hamid Abu Zayd, Farid Esack, Abdullah Ahmed an-Naim, Muhammad Abid al-Jabiri dan lain-lain. Merekalah yang sesungguhnya telah mengaktualkan metodologi keilmuan filsafat dalam persoalan-persoalan kalam dan akidah Islamiyah. ${ }^{8}$ Sebab "filsafat" adalah "metode berpikir". Berpikir kritis-analitis dan sistematis. Ia lebih mencerminkan "proses" berpikir. Dan bukan sekedar "produk" berpikir. Dalam "proses" berpikir itulah metodologi filsafat dapat diaktualisasikan dalam pemikiran kalam. Tanpa dibarengi sentuhan filsafat, agama dan kekuatan spiritual yang lain dalam era globalisasi budaya akan semakin sulit memerankan jati dirinya, terutama bagi pengembangan keilmuan kalam dalam menetap realitas sosial keagamaan di masa depan. ${ }^{9}$

Dengan demikian, mengaktualkan metodologi filsafat dalam pokok-pokok persoalan pemikiran kalam, akan menciptakan sesuatu yang aktual dan relevan dengan tingkat perkembangan historitas pemikiran manusia muslim itu sendiri, sekaligus relevan dengan pemikiran manusia pada umumnya,

\footnotetext{
${ }^{4}$ M. Amin Abdullah, "Kajian Ilmu Kalam" dalam Komaruddin Hidayat dan Hendro Prasetyo (ed.), Problem dan Prospek IAIN Antologi Pendidikan Tinggi Islam, (Jakarta: Dibinpertais Depag, 2000), h. 222.

${ }^{5}$ M. Amin Abdullah, Problem dan Prospek IAIN, h. 222

${ }^{6}$ M. Amin Abdullah, Interelasi Imun Kalam Dengan Ilmu Lainya. Makalah Seminar dalam Forum Pertemuan Dosen Ilmun Kalam IAIN se Indonesia, (Bogor: Wisma YPI, 1993), h. 12

${ }^{7}$ Adeng Muchtar Ghazali, Pemikiran Islam Kontemporer Suatu Refleksi Keagamaan yang Dialogis, (Bandung: Pustaka Setia, 2005), h. 132-133.

${ }^{8}$ M. Amin Abdullah, Problem dan Prospek IAIN, h. 235.
} 
serta akan memberikan makna dan mengangkat asset kerohanian manusia muslim dalam era kontemporer sekarang ini.

\section{Metodologi Pemikiran Kalam Klasik}

Sebagaimana telah disinggung di atas bahwa metodologi pemikiran kalam klasik ${ }^{10}$ adalah bangunan pemikiran kalam yang dibentuk oleh zaman yang berkembang pada saat itu. Dimana metodologi pemikiran kalam klasik dibagun dalam suasana merespon terhadap hingar-bingar perpecahan politik akibat pembunuhan khalifah ketiga Usman bin Affan, yang terjadi pada tahun 35 Hijriyah, ${ }^{11}$ yang kemudian berlanjut dengan terbunuhnya khalifah keempat Ali bin Abi Thalib pada tanggal 17 Ramadhan $40 \mathrm{H}^{12}$ Adapun metodologi pemikiran kalam yang pertama muncul yang berkaitan langsung dengan peristewa politik, kemudian bergeser kepada timbulnya masalah-masalah akidah, siapa yang kafir dan bukan kafir dalam artian siapa yang telah keluar dari Islam dan siapa yang masih tetap Islam. ${ }^{13}$ Dan berkenaan tentang posisi orang yang berdosa besar, seperti pembunuh Usman, Ali dan Mu'awiyah yang terlibat dalam perang Siffin dan tahkim, serta Talhah, Zubair, Aisyah yang memberontak kepada khalifah Ali dalam parang Jamal. Semua yang mereka tersebut di atas apakah mereka tetap muslim atau kafir. Dalam perjalanan selanjutnya wacana metodologi pemikiran kalam klasik itu kemudian diramu dengan bahan-bahan yang berasal dari filsafat Yunani, sehingga menimbulkan pemikiran kalam yang semula berwatak "metafisik-normatif", kemudian bertambah menjadi berwatak "deduktif-spikulatif" dan secara keseluruhannya, pemikiran kalam klasik hanya berorientasi "teosentris". Dengan wataknya yang bersifat metafisik-normatif dan deduktif-spekulaitif serta berorientasi pada dimensi teosentris semata, maka tidak mengherankan bila pemikiran kalam klasik kurang ataubahkan tidak memiliki kepekaan terhadap persoalan-persoalan sosial umat dan pesoalan kemanusian universal. ${ }^{14}$

Adapun metodologi berpikir kalam klasik dapat diindentifikasikan berdasarkan pola pemikiran nonfilosofis dan filosofis. Pola pikir nonfilosofis ditujukan kepada pemikiran-pemikiran kalam yang yang berawal dari pertikaian politik, sedangkan pola pemikiran filosofis, diutujukan terutama kepada aliran kalam yang bersentuhan langsung dengan pemikiran filsafat Yunani termasuk dalam penggunaan metodologinya. Model cara berpikir ini menunjukkan adanya karakteristik yang berbeda baik dari sisi subtansi dan metodologinya. Secara subtansial, yaitu materi wilayah kajian, tidak begitu berbeda jauh, sedangkan dari segi kerangka berpikirnya mempunyai pola pikir yang jauh berbeda. Oleh sebab itu, aspek metodologi mendapat penekanan khusus berkaitan dengan perkembangan pola pikir di lingkungan mutakallimin, terutama setelah masuknya unsur filsafat dan pemahaman-pemahaman

\footnotetext{
${ }^{9}$ M. Amin Abdullah, Problem dan Prospek IAIN, h. 241

${ }^{10}$ Pembicaraan tentang kalam klasik tidak terlepas dari perkembangan sejarah Islam, menurut Harun Nasution yang dikutip oleh Adeng Muchtar Ghazali, mengatakan bahwa periodesasi sejarah Islam ada tiga periode besar yaitu: Pertama, periode klasik (650-1250 M.) yang merupakan zaman kemajuan, terbagi dua fase yaitu: fase ekspansi, integrasi dan puncak kemajuan (6501000 M.) Adapun fase disintegrasi di awali ketika Baghdad dapat dirampas dan dihancurkan oleh Hulagu pada tahun1258 M. Kedua, periode pertengahan (1250-1800 M.) ditandai dengan fase kemunduran (1250-1500 M.) dari tahun 150-1700 M. zaman kemajuan, kemudian tahun 1700-1800 M. zaman kemunduran umat Islam. Ketiga, periode modern (1800 M. - sekarang ) merupakan zaman kebangkitan umat Islam. Lihat: Adeng Muchtar Ghazali, Perkembangan Ilmu Kalam, h. 10-12

${ }^{11}$ HadariansyahAB, Pemikiran-Pemikiran Teologi dalam Sejarah Pemikiran Islam, (Banjarmasin: Antasari Press, 2010), h. 13

${ }^{12}$ Salihun A. Nasir, Pemikiran Kalam (Teologi Islam): Sejarah, Ajaran, dan Perkembangannya, (Jakarta: PT RajaGrafindo Persada, 2010), h. 81

${ }^{13}$ Harun Nasution, Teologi Islam Aliran-Aliran Sejarah Analisa Perbandingan, (Jakarta: Yayasan Universitas Indonesia, 1972), h. 6

${ }^{14}$ Mustafa P., M. Quraish Shibab Membumikan Kalam di Indonesia, (Yogyakarta: PustakaPelajar, 2010), h. 34-35
} 
keagamaan lain kedalam pemikiran masayarakat Islam. ${ }^{15}$

Adapun sarana atau alat yang digunakan dalam metodologi pemikiran kalam klasik pada abad pertama dalam sejarah Islam, berupa 'aqal (akal) dan naql (wahyu). Sarana akan dapat digunakan, apabila tujuan untuk memperkuat dan mempertahankan keyakinan akidahnya dalam perdebatan dan pergumulan dalam pemikiran kalam, disini peranan akal untuk merumuskan pemikiran ketuhanan secara rasional. Dari produk akal ini akan melahirkan berupa kesimpulan intelektual, dimana kesimpulan intelektual dalam persoalan kalam ini pada dasarnya hanya untuk keperluan ilmu pengatahuan, kurang mengacu untuk pemantapan akidah seseorang. Pendekatan rasional ini terjadi sejak pertemuan Islam dengan peradaban non Islam dan berbagai tradisi serta pemikiran keagamaan yang telah mendorong mutakallimin untuk lebih banyak lagi memberikan perhatian pada masalahmasalah yang bercorak rasional-filosofis. Debat kalamiyah pada saat itu benar-benar mewarnai pertumbuhan metodologi pemikiran kalam klasik, sebagai contoh adanya perdebatan paham ketuhanan antara Mu'tazilah dengan Asy'ariyah dan para pengikutnya tidak terlepas dari prinsipprinsip kalam para pendirinya. ${ }^{16}$

Adapun sarana naql (wahyu) merupakan alat atau sandaran utama dalam pembahasan kalam. Kebenaran hakiki untuk diimani telah tercantum dalam al-Qur'an, dengan demikian langkah utama dalam memahami akidah Islam adalah dengan memahami al-Qur'an. Misalnya yang berkaitan dengan zat Allah, al-Qur'an menjelaskan mengenai Allah dan sifat-sifat-Nya dengan apa yang disebut dengan asmâ al-husna (nama-nama Allah yang paling indah). Sejumlah nama Allah itu pada hakikatnya mempunyai implikasi akidah. ${ }^{17}$

Sebagai contoh dalam metodologi pemikiran kalam klasik, dapat dibedakan yaitu metodologi pemikiran kalam Mu’tazilah, Salafiyah dan Asy’ariyah. Metodologi pemikiran kalam Mu’tazilah digolongkan kepada metodologi kalam rasional, dinama naql harus tunduk dibawah akal. Namun para tokoh-tokohnya tetap tidak melupakan teks-teks wahyu (al-Qur'an dan al-hadis) dalam memformulasikan pendapat-pendapatnya. Al-Qur'an dan al-hadis adalah sumber pokok kepercayaan yang mereka yakini kebenarannya. Hanya saja, sesuai dengan metode rasional yang mereka pegang teguh, yang sangat menjunjung tinggi akal, ayat-ayat al-Qur'an yang sesuai dan diterima akal, mereka jadikan sebagai pendukung pendapat-pendapat mereka, sedangkan yang tidak demikian mereka takwilkan secara rasional atau dilewatkan begitu saja. Demikian pula halnya terhadap hadis, meskipun hadis sahih oleh ahli hadis. ${ }^{18}$

Sedangkan pemikiran kalam Salafiyah dari segi metodologinya berbeda secara diametral dengan Mu'tazilah, dimana Salafiyah ini mengutamakan penggunaan metode tekstual, yang mengharuskan akal tunduk di bawah naql. Namun, dalam penerapannya di kalangan tokoh-tokoh aliran ini, metode ini tidak selalu membuahkan hasil yang sama. Hal ini disebabkan mereka tak luput dari pengaruh situasi kultural dan struktural pada masanya. ${ }^{19}$

Adapun metodologi pemikiran kalam yang dipergunakan Asy'ariyah berbeda dari metodologi Salafiyah, meskipun keduanya sama-sama mengakui golongannya sebagai golongan Ahlusunah wal jama'ah dalam teologi Islam. Metode yang dipergunakan al-Asy'ari memang unik, berbeda dari kedua

${ }^{15}$ Adeng Muchtar Ghazali, Perkembangan Ilmu Kalam, h. 36

${ }^{16}$ Bahran Noor Haira, et,al., Rancang Bangun Teologis Masyarakat Banjar (Studi Konstruksi Metodologis Penulisan Kitab Taubid), Laporan Penelitian, (Banjarmasin: Pusat Penelitian IAIN Antasari IAIN Antasari, 2006), h. 8-9.

${ }^{17}$ Bahran Noor Haira, et,al., Rancang Bangun....... h. 9-10

${ }^{18}$ M. Zurkani Jahja, Teologi al-Ghazali: Pendekatan Metodologi, (Yogyakaaarta: Pustaka Pelajar, 1996), h. 34-35

${ }^{19}$ M. Zurkani Jahja, Teologi al-Ghazali:........., h. 36 
metode aliran yang tersebut di atas, dimana metodenya bisa dikatakan sebagai sintesa antara keduanya. Al-Asy'ari mengambil yang baik dari metode rasional Mu'tazilah dan metode tekstual Salafiyah, sehingga dalam penggunaan akal dan naql secara seimbang, menggunakan akal secara maksimal tetapi tidak sebebas Mu'tazilah, dan memegang naql dengan kuat tetapi tidak seketat Salafiyah dalam menolak akal untuk menjamahnya. ${ }^{20}$

Metode sintesa Asy'ariyah ini, dianggap sebagai metode moderat, walaupun dalam operasionalnya mengalami perkembangan, baik pada diri al-Asy'ari sendiri maupun pada tokohtokoh pendukungnya dalam beberapa abad sesudahnya. Perkembangan tersebut berupa besarnya porsi yang diberikan kepada salah satu sisi metodenya yang penting (akal dan naql), sehingga ada kesan mendekatinya metode tersebut kepada metode salah satu aliran yang lain. Misalnya al-Asy'ari dalam karyanya al-Ibanah 'an Ushul ad-Diyanah, lebih banyak menggunakan metode tekstual, yaitu dengan menjadikan naql sebagai dasar, dan akal sebagai argumen penguatnya. Sedangakan dalam karyanya al-Luma', al-Asy'ari telah mempergunakan argumen rasional lebih dahulu kemudian disusul dengan argumen tekstual, sehingga nampak ada keseimbangan antara metode rasional dan metode tekstual dalam dirinya. Jadi dalam penerapannya, metode Asy'ariyah sendiri ini juga bervariasi, baik pada al-Asy'ari sendiri maupun pada para pendukungnya. ${ }^{21}$

Dengan demikian metodologi pemikiran kalam klasik tidak terlepas dari pola pemikiran nonfilosofis dan filosofis yang mempunyai karakteristik yang berbeda satu sama lain, namun tidak terlepas dari referensi utama al-Qur'an dan al-hadis sebagai dasar agama yang harus dipegang teguh.

\section{Metodologi Pemikiran Kalam Kontemporer}

Sebagaimana telah diuraikan di atas, bahwa metodologi pemikiran kalam klasik yang selama ini kita pelajari, sangat sarat diwarnai oleh interes-interes politik. Jika masing-masing kelompok politik mempunyai definisi tersendiri tentang persoalan-persoalan kalam, seperti tentang masalah dosa, neraka, kafir, mukmin, sifat-sifat Tuhan dan sebagainya, untuk menegaskan pendirian politiknya terhadap pihak lawan, maka jika pandangan ini masih tetap dipertahankan, tak dapat dibayangkan betapa banyaknya sekte (firqah) yang akan saling mencurigai antara yang satu kelompok dengan kelompok lainnya. Lebih parah lagi jika masing-masing kelompok politik mengklim bahwa hanya pandangan mereka sajalah yang benar (truth claim) sedangkan yang lain salah.

Kalau pemikiran kalam tidak dapat dipisahkan dari dominasi kekuasaan politik, maka esensi dan subtansi pemikiran kalam yang termanifestasikan dalam etika sosial dan spritualitas keberagamaan kurang mendapat porsi yang menggigit dalam tradisi keilmuan kalam. Ironisnya, tradisi keilmuan ini turun temurun secara berkesinambungan dipelajari diberbagai kalangan masyarakat muslim saat ini. Sehingga jargon sosiologisnya menjadi begitu sederhana, yaitu muslim atau kafir. Oleh karena itu kita perlu membedakan analisis mana yang menjadi alat dan mana yang menjadi tujuan. ${ }^{22}$

Kelemahan pemikiran meteodologi kalam selama ini telah kita disadari, tetapi kurangnya informasi dan kurang memiliki semangat untuk itu, maka akhirnya pemikiran ini terhenti. Padahal dalam pemikiran metodologi kalam sebenarnya lebih kaya nuansa pemikiran-pemikiran yang dinamis dan filosofis daripada hanya didominasi konspirasi politik. Sebagaimana pendapat Amin Abdullah, yang dikutip oleh Adeng MuchtarGhazali mengatakan bahwa keberagamaan manusia tidak semata-

\footnotetext{
${ }^{20}$ M. Zurkani Jahja, Teologi al-Ghazali, h. 41-42.

${ }^{21}$ M. Zurkani Jahja, Teologi al-Ghazali, h. 42.

${ }^{22}$ Adeng Muchtar Ghazali, Perkembangan Ilmu Kalam, h. 134.
} 
mata terkurung oleh faktor sosiologis, politis atau psikologis, namun juga termuat didalamnya nuansa pemikiran transcendental-filosofis. Konsepsi ketuhanan yang bersifat eksklusif (having a religion) dan yang bersifat insklusif (being religios) perlu ditelaah ulang dari sudut pandang al-Qur'an dan al-hadis dengan menggunakan alat atau pendekatan komprehensif. ${ }^{23}$

Dengan demikian diperlukan alat bantu metodologi yang dapat melihat secara jernih dimana wilayah yang sebenarnya menyangkut persoalan filosofis, yakni wilayah yang terkait dengan fundamental values, dimana wilayah yang menyangkut aspek-aspek sosiologis politis, dan di mana wilayah yang dimungkinkan berlakunya pendekatan yang bersifat eksklusif maupun inklusif, atau wilayah yang sebenarnya tumpang tindih antara keduanya.

Di samping itu, kajian-kajian tentang aliran kalam selama ini tampak sekali kurang nuansa pemikiran sejarah dan pendekatan sosial. Seharusnya kedua pendekatan ini penting digunakan sebagai telaah kritis terhadap aliran-aliran kalam untuk memungkinkan munculnya muatan baru metodologi kalam yang lebih bernuansa kontemporer. Diharapkan metodologi pemikiran kalam kontemporer yang hidup untuk era sekarang ini adalah sebuah metodologi pemikiran kalam yang berdialog dengan realitas dan perkembangan pemikiran manusia yang berjalan saat ini, bukannya metodologi pemikiran kalam yang berdialog dengan masa lalu. Telaah masa silam di perbolehkan saja, setidaknya sekedar untuk memenuhi rasa keingintahuan (kuriositas) manusia terhadap perkembangan manusia.

Oleh karena itu, metodologi pemikiran kalam kontemporer seharusnya dapat memahami perkembangan pemikiran manusia kontemporer, yang diakibatkan oleh perubahan politik dan sosial budaya yang dibawa oleh arus ilmu pengetahuan dan teknologi. Jelasnya, jika metodologi pemikiran kalam klasik berdialog dan bergaul dengan format pemikiran serta epistemologi Yunani (Hellenisme), maka metodologi pemikiran kalam kontemporer harus bersentuhan dengan pemikiran filsafat Barat kontemporer, yang di bentuk dan diilhami oleh arus perubahan yang diakibatkan oleh perkembangan ilmu pengetahuan dan teknologi. ${ }^{24}$

Tentu kita telah menyadari bahwa, pada situasi sekarang ini tidak ada satu pun kekuasaan spiritual, kriteria objektif, karya yang dimuliakan, yang memungkinkan untuk menentukan secara tegas Islam yang sebenarnya. Hal ini berarti bahwa segala masalah pemikiran kalam atau ketuhan yang ditelaah oleh ulama-ulama zaman dulu harus di buka dan ditelaah kembali sesuai dengan perubahan cara pandang dan pemikiran yang sedang berlangsung. Oleh karena itu, tantangan pemikiran kalam kontemporer adalah isu-isu kemanusiaan yang berkembang secara universal, pluralisme keagamaan, kemiskinan struktural, kerusakan lingkungan dan lain sebagainya. Pemikiran kalam yang hanya membicarakan tentang Tuhan (teosentris) dan tidak mengkaitkan diskursusnya dengan persoalan kemanusiaan universal (antroposentris), maka rumusan pemikiran kalamnya lambat laun akan terjadi out of date. Sebagai contoh, yang disebut "kafir" dalam konteks sosiologis sekarang adalah orang yang membiarkan orang miskin di lingkungan terdekatnya mati kelaparan, hal ini tentunya bukan hanya bagi orang yang tidak sepaham atau seagama dengan dirinya. ${ }^{25}$

Demikian pula dalam kehidupan sosial kemasyarakatan misalnya, sering terjadi perasaan kikuk karena harus bertetangga dengan orang yang kebetulan penganut agama lain. Sebagai umat islam merasa tidak berbuat kebaikan (pahala) dan beramal saleh, ketika mereka menolong tetangga yang kebetulan tidak seagama. Jika demikian fakta empiris yang bisa dijumpai dalam kehidupan faktual

\footnotetext{
${ }^{23}$ Adeng Muchtar Ghazali, Pemikiran Islam Kontemporer, h. 140

${ }^{24}$ Adeng Muchtar Ghazali, Pemikiran Islam Kontemporer, h. 141

${ }^{25}$ Adeng Muchtar Ghazali, Perkembangan Ilmu Kalam, h. 133
} 
bertetangga sehari-hari, dapat dibayangkan betapa kerasnya reaksi sebagian umat Islam jika ada kelompok umat Islam tertentu yang megajak "kerjasama" dan bergabung dengan kelompok penganut agama lain dalam suatu kekuatan politik. Di sinilah gambaran betapa sekat-sekat teologis, akidah dan kalam yang dikonsepsikan dan dirumuskan era klasik-skolastik terus menerus dipelihara oleh umat beragama dewasa ini. Umat beragama pada umumnya kurang senang dan tidak begitu nyaman melihat fenomena sosial keagamaan yang bersifat plural, padahal fenomena plural tersebut terus berkembang dalam dunia praksis sosial keagamaan. ${ }^{26}$

Demikian pula mendefinisikan tentang konsepsi pahala dan dosa, yang selama ini dikenal bahwa pahala dan dosa selalu dimaknai secara teologis, abstrak dan eskatologis, semata-mata urusan kita di akhirat kelak. Seharusnya pahala dan dosa diorientasikan pada pengertian yang bersifat sosiologis. Misalnya dalam hukum sosial, kita harus berjalan melalui jalur sebelah kiri, kalau kita berjalan di sebelah kanan meskipun secara teologis tidak berdosa, tetapi secara sosial dia sesungguhnya berdosa, karena dapat menggangu keseimbangan dan bisa terjadi kecelakaan. Dengan demikian pahala bisa berarti sesuatu yang mendorong terjadinya keserasian dan keseimbangan sosial. ${ }^{27}$

Dalam masalah norma agama sebagai kekuatan budaya (cultural force), tidak ada yang meragukan betapa kuat dan kokohnya kepercayaan umat Islam terhadap keberadaan dan keagungan Allah Swt. Namun kekuatan keimanan ini belum dihadapkan pada persoalan-persoalan aktual dan kongkrit yang dihadapi umat manusia dalam kehidupan sehari-hari sehingga tampak kurang dimanfaatkan sebagai kekuatan budaya (cultural force). Sebagai contoh, penggunaan istilah "iman dan taqwa" (imtaq) yang biasa disitir oleh para pejabat, juru dakwah dan penceramah keagamaan, menunjukkan praktik imtaq dalam praksis sosial sangatlah lemah dan hanya merupakan slogan dalam berpidato, namun tidak terlaksana dalam praktik. Misalnya telah membudayanya KKN (korupsi, kolusi dan nepotesme) di hampir seluruh lini kehidupan masyarakat di tanah air kita dewasa ini. Ketika umat Islam Indonesia dihadapkan isu aktual dan kongkrit seperti KKN, ternyata kebanyakan mereka justru kurang peka terhadap isu tersebut jangankan memberi solusi yang mudah diterapkan (aplikabel) dalam kehidupan masyarakat luas, mereka baru sadar bahwa ternyata di luar pagar sistem peribadatan murni (mabdhah) terhadap kekuatan yang lebih dahsyat yang dapat memporak-porandakan sendi-sendi kekuatan moral atau spiritual (moral, spiritual force) keagamaan perorangan, keluarga, masyarakat maupun bangsa. Ternyata penyakit KKN tidak dapat diobati melalui himbauan dan ajakan retorika keagamaan, KKN mempunyai logika dan mekanisme kerja tersendiri, yang terlepas dan luput dari pengamatan dan telaah sistem peribadatan pribadi umat Islam (al-abwâl asy-syakhsiyyah) yang bisa ditekuni selama ini.

Dalam telaah teoritik ilmu-ilmu sosial, KKN termasuk dalam wilayah public morality (kesalehan publik) bukan semata-mata dalam wilayah individual morality (kesalehan pribadi). Wilayah individual morality barang kali memang cukup dibekali dan diselesaikan melalui pendekatan al-ab̂wâl asysyakhsiyyah, sedangkan persoalan public morality mempersyaratkan dikuasainya seperangkat keilmuan critical social sciences yang diharapkan dapat menciptakan sistem kontrol sosial yang handal. ${ }^{28}$

Dalam hal ini pemerintah Indonesia melalui keppres No. 17 tahun 1994 tentang repelita VI, telah mencoba melalui Departemen Agama (sekarang Kemeterian Agama) untuk menyebarluaskan

\footnotetext{
${ }^{26}$ M. Amin Abdullah, Problem dan Prospek IAIN, h. 233

${ }^{27}$ Rumadi, Puasa dan Kesalehan Sosial, dalam M. Imdadun Rahmat (ed.) Islam Pribumi; Mendialogkan Agama Membawa Realitas, (Jakarta: Erlangga, 2003), h. 80.

${ }^{28}$ M. Amin Abdullah, Problem dan Prospek IAIN, h. 235 - 236.
} 
pegawasan melalui jalur agama, yang tujuannya adalah agar tumbuhnya budaya malu dan rasa berdosa terhadap perilaku menyimpang dalam rangka menegakkan dan memulihkan kembali nilai-nilai yang benar. ${ }^{29} \mathrm{Hal}$ ini tentunya sangat erat hubungannya dengan pembinaan keimanan seseorang kepada Allah Swt. sehingga dia selalu merasa diawasi dan diketahui oleh Allah segala tindak tunduknya di dunia ini. Disamping itu merasa malu terhadap masyarakat apabila dia melakukan hal-hal yang bertentangan dengan moral agama.

Dalam kenyataannya kepedulian terhadap isu-isu aktual, isu-isu publik, kepentingan-kepentingan umum agaknya kurang mendapat respon oleh masyarakat, juga kurang diperhatian oleh dogmadogma agama dan ilmu kalam. Untuk itulah agar metodologi pemikiran kalam kontemporer dapat diperankan dalam memecahkan problem kehidupan sosial yang aktual dan kongkrit, ia harus bersedia menjalin kerja sama dengan pendekatan critical social sciences dan humaniora pada umumnya. Jika tidak, maka ilmu kalam, akidah atau dogma hanya akan bermakna secara esoteris-metafisis tetapi kurang begitu peduli, apalagi sampai terlibat dalam pergumulan isu-isu sosial-eksoterik yang sedang digelisahkan oleh umat manusia dewasa ini.

Dengan demikian gagasan-gagasan seperti inilah yang perlu kita upayakan, yakni pergeseran wilayah pemikiran yang dulunya hanya memikirkan persoalan-persoalan teologi (ketuhanan) klasik kearah paradigma pemikiran yang lebih menelaah dan mengkaji secara serius persoalan-persoalan kemanusiaan yang berkembang saat ini. Tentunya muatan metodologi pemikiran kalam kontemporer yang digagas ini, tetap berpegang teguh secara mutlak kepada al-Qur'an dan al-hadis, sebagai sumber utama pemikiran kalam, disamping penalaran sebagai media untuk melakukan upaya ijtihadi.

\section{Penutup}

Metodologi pemikiran kalam dalam Islam lahir dan berkembang penuh vitalitas dan dinamis, sebagai suatu upaya ijtihadi seseorang atau sekelompok orang untuk menerjemahkan nilai-nilai universalitas al-Qur'an dan al-hadis, sebagai cara untuk mengekspresikan pandangan pemikiran kalamnya, kemudian dijaga dan dipertahankan melalui argumentasi yang logis-rasional, yang disesuaikan dengan situasi dan kondisi zaman. Metodologi pemikiran kalam klasik merupakan jawaban terhadap persoalan-persoalan kalam pada zamannya, yang dapat diindentifikasikan berdasarkan pola pikir nonfilosofis dan filosofis. Pola pikir nonfilosofis ditujukan kepada pemikiran kalam yang berawal dari pertikaian politik, sedangkan pola pikir filosofis, terutama bagi aliran kalam yang bersentuhan langsung dengan pemikiran filsafat Yunani yang hanya berorientasi pada dimensi teosentris semata. Dengan wataknya yang bersifat metafisik-normatif dan deduktif-spekulaitif, maka tidak mengherankan bila pemikirakan kalam klasik kurang atau bahkan tidak memiliki kepekaan terhadap persoalanpersoalan sosial umat dan pesoalan kemanusian universal.

Sedangkan metodologi pemikiran kalam kontemporer bersentuhan dengan pemikiran filsafat Barat kontemporer dewasa ini, kehadirannya tidak melulu upaya apoligetik membela Tuhan, tapi diharapkan dapat membantu mengatasi dan memecahkan persoalan-persoalan kemasyarakatan dewasa ini, dan lebih peka terhadap problema umat dan isu-isu kemanusiaan universal, agar pemikiran kalam lebih "membumi" relevan dengan permasalahan kekinian dan berusaha memberikan solusi dengan memberikan pemaknaan yang lebih bersifat "antroposentris" dan menempatkan manusia sebagai pusat kesadaran. Tentunya muatan metodologi kalam klasik dan kalam kontemporer, tetap berpegang

${ }^{29}$ Departemen Agama RI, Petunjuk Pelaksanaan Penyebarluasan Pengertian dan Kesadaran Pengawasan Melalui Jalur Agama, (Jakarta: Inspektorat Jenderal, 1997), h. 20. 
teguh secara mutlak kepada al-Qur'an dan al-hadis, sebagai sumber utama metodologi pemikiran kalam, disamping penalaran sebagai media untuk melakukan upaya ijtihadi.

\section{DAFTAR PUSTAKA}

Abdullah, M. Amin, (1993). Interelasi Ilmun Kalam Dengan Ilmu Lainya. Makalah Seminar dalam Forum Pertemuan Dosen Ilmun Kalam IAIN se Indonesia, Bogor: Wisma YPI.

_- (2000). "Kajian Ilmu Kalam” dalam Komaruddin Hidayat dan Hendro Prasetyo (ed.), Problem dan Prospek IAIN Antologi Pendidikan Tinggi Islam, Jakarta: Dibinpertais Depag.

Departemen Agama RI, (1997). Petunjuk Pelaksanaan Penyebarluasan Pengertian dan Kesadaran Pengawasan Melalui Jalur Agama, Jakarta: Inspektorat Jenderal.

Ghazali, Adeng Muchtar, (2005). Perkembangan Ilmu Kalam Dari Klasik Hingga Modern, Bandung: Pustaka Setia.

—, (2005). Pemikiran Islam Kontemporer Suatu Refleksi Keagamaan yang Dialogis, Bandung: Pustaka Setia.

Haira, Bahran Noor, (2006). et,al., Rancang Bangun Teologis Masyarakat Banjar (Studi Konstruksi Metodologis Penulisan Kitab Taubid), Laporan Penelitian, Banjarmasin: Pusat Penelitian IAIN Antasari IAIN Antasari.

Jahja, M. Zurkani, (1996). Teologi al-Ghazali: Pendekatan Metodologi, Yogyakarta: Pustaka Pelajar.

Nasution, Harun, (1972). Teologi Islam Aliran-Aliran Sejarah Analisa Perbandingan, Jakarta: Yayasan Universitas Indonesia.

Maulana, Achmad et.al.,(2004). Kamus Ilmiah Populer, Yogyakarta: Absoulut.

Mustafa P., (2010). M. Quraish Shihab Membumikan Kalam di Indonesia, Yogyakarta: PustakaPelajar.

Mustansyir, Rizal dan Misnal Munir, (2004), Filsafat Ilmu, Yogyakarta: Pustaka Pelajar.

Rumadi, Puasa dan Kesalehan Sosial, dalam M. Imdadun Rahmat (ed.), (2003). Islam Pribumi; Mendialogkan Agama Membawa Realitas, Jakarta: Erlangga. 